\title{
Título da página electrónica: Z Net - A Community of People Commited to Social Change
}

Endereço: http://www.zmag.org/weluser

José Manuel Mendes

\section{OpenEdition}

\section{Journals}

Edição electrónica

URL: http://journals.openedition.org/rccs/1067

DOI: $10.4000 /$ rccs. 1067

ISSN: 2182-7435

\section{Editora}

Centro de Estudos Sociais da Universidade de Coimbra

Edição impressa

Data de publição: 1 dezembro 2004

Paginação: 211

ISSN: 0254-1106

Refêrencia eletrónica

José Manuel Mendes, «Título da página electrónica: Z Net - A Community of People Commited to Social Change », Revista Crítica de Ciências Sociais [Online], 70 | 2004, posto online no dia 01 outubro 2012, consultado o 22 setembro 2020. URL : http://journals.openedition.org/rccs/1067 ; DOI : https:// doi.org/10.4000/rccs. 1067 


\section{Espaço Virtual}

\section{Título da página electrónica: Z Net - A Community of People Commited to Social Change Endereço: http://www.zmag.org/weluser}

Esta página electrónica inclui-se no projecto $Z$ Communications - The Spirit of Resistance Lives, uma iniciativa lançada por Michael Albert e Lydia Sargent que propõe uma visão crítica e alternativa ao sistema capitalista mundial. Entre os vários colaboradores desta página contam-se, entre outros, Noam Chomsky, Arundhati Roy e Vandana Shiva, com muitos documentos próprios disponíveis.

Entre as várias secções que constituem esta página, são de salientar as seguintes: a revista $Z$ Magazine com algumas edições e o arquivo acessíveis a todos os visitantes; os blogues dos autores já referidos e de muitos outros; os recursos, que estão divididos tematicamente, desde os media alternativos até ao multiculturalismo; e, de forma especialmente relevante, a secção ParEcon, dedicada à economia participativa. Este última secção baseia-se nos princípios da equidade, da solidariedade, da diversida- de e da autogestão participativa, e apresenta-se como o resultado de uma reflexão teórica aturada e sustentada sobre os processos e as lógicas organizativas que possibilitem um tipo de economia que se consolide como uma verdadeira alternativa ao capitalismo.

A página $Z$ Net mantém um conjunto de artigos e de propostas sobre a actualidade que são de realçar, sendo introduzidos novos contributos diariamente. A página está muito bem desenhada e, apesar de conter o que parece um excesso de informação, tal acaba por não ser uma desvantagem, dado que obriga o visitante a passear pela mesma e a descobrir os conteúdos que mais interesse lhe despertam. Esta página afigura-se como uma referência obrigatória para todos os que se interessam pelos movimentos sociais e propostas políticas críticas e alternativas à globalização e ao capitalismo neoliberal.

\section{Título da página electrónica: Pour Lire Pas Lu Endereço: http://www.homme-moderne.org/plpl/}

Esta página em forma de jornal apresenta-se como um espaço de crítica radical aos meios de comunicação de referência em França e na Europa. Tem como um dos seus mentores Serge Halimi, autor próximo da escola de Pierre Bourdieu e um crítico acérrimo dos media e do sistema capitalista. Apesar do radicalismo de algumas das suas posições, os autores acolhidos nesta página dão-nos uma perspectiva problemati- zadora da concentração dos media e dos desafios teóricos e éticos que se colocam aos jornalistas e aos especialistas das ciências sociais e humanas na produção de notícias e de conteúdos sobre as dinâmicas sociais e as lógicas de poder na Europa e nos Estados Unidos.

A página dá acesso a alguns artigos publicados na revista em versão impressa e a alguns dossiers, dos quais se salienta o que 
analisa de forma pormenorizada o assalto fantasma a uma mulher no Metro de Paris e toda a efabulação anti-racista posterior induzida pelas notícias produzidas nos órgãos de comunicação de âmbito nacional.
Esta página tem um desenho pouco apelativo mas é de fácil consulta e é um recurso importante para todos os que estudam os processos de produção e difusão de media alternativos.

\section{Título da página electrónica: Pamela Oliver Homepage Endereço: http://www.ssc.wisc.edu/ oliver/}

Esta é a página pessoal de Pamela Oliver, professora do Departamento de Sociologia na Universidade de Wisconsin-Madison, nos Estados Unidos. A autora é especialista no estudo dos movimentos sociais e no protesto social, tanto numa vertente quantitativa como qualitativa.

Realço nesta página a secção intitulada Protest Dynamics (Dinâmicas de Protesto). Entre os vários artigos disponibilizados, são de especial importância os que se atêm à análise do papel dos media na construção dos acontecimentos de protesto. A autora é também responsável por uma proposta analítica apoiada em modelos formais de evolução dos movimentos de protesto que tem tido alguma difusão entre os especia- listas que abordam esta temática. Também temos acesso nesta secção a uma lista interessante de ligações pertinentes relacionadas com o tema dos movimentos sociais. Aqui é-nos oferecida uma lista de filmes relevantes para o estudo dos movimentos sociais que merece especial atenção por parte dos que se interessam pelo uso de materiais audiovisuais como ferramentas pedagógicas.

A página tem um desenho simples e, não sendo apelativa, contém documentação importante para o estudo dos movimentos sociais.

José Manuel de Oliveira Mendes jomendes@fe.uc.pt 